\title{
Disparity Of Death Penalthy Decision Against People Criminal Acts Of Dark Circular Narcotics
}

\begin{tabular}{|c|c|}
\hline & $\begin{array}{l}\text { Yogi Prasetya Sinambela }{ }^{1} \\
\text { is Muhammadiyah Sumatera Utara, Indonesia }\end{array}$ \\
\hline ARTICLE INFO & ABSTRACT \\
\hline $\begin{array}{l}\text { Article history: } \\
\text { Received Nov 27, } 2019 \\
\text { Revised Jan 05, 2020 } \\
\text { Accepted March 05, } 2020\end{array}$ & $\begin{array}{l}\text { According to Law NUMBER } 35 \text { of } 2009 \text { concerning Narcotics. } \\
\text { Regulate the death penalty for drug traffickers listed in article } 114 \\
\text { paragraph (12), article } 119 \text { paragraph (2) and article } 121 \text { paragraph } \\
\text { (2) which can impose the death penalty that has evidence exceeding } 5 \\
\text { (five grams) and narcotics groups } 1 \text { and } 2 \text {. The purpose of the study }\end{array}$ \\
\hline $\begin{array}{l}\text { Keywords: } \\
\text { Disparity, } \\
\text { Capital Punishment, } \\
\text { Illicit Circulation, } \\
\text { Narcotics }\end{array}$ & $\begin{array}{l}\text { is to find out how the regulation of capital punishment against } \\
\text { perpetrators of criminal acts of illicit drug trafficking and how capital } \\
\text { punishment disparities against perpetrators of illicit trafficking in } \\
\text { narcotics as well as criminal law policies to overcome the disparity in } \\
\text { the death penalty for perpetrators of illegal drug trafficking through } \\
\text { approach according to Law Number } 35 \text { of } 2009 \text { concerning } \\
\text { Narcotics. The research conducted juridical legal research with a }\end{array}$ \\
\hline $\begin{array}{l}\text { Clonflict of Interest: } \\
\text { None }\end{array}$ & $\begin{array}{l}\text { studies and secondary data by processing data from primary legal } \\
\text { materials, secondary legal materials and tertiary legal materials. } \\
\text { Based on the results of the study, it was understood that the }\end{array}$ \\
\hline $\begin{array}{l}\text { Funding: } \\
\text { None }\end{array}$ & $\begin{array}{l}\text { illicit drug trafficking could be carried out by the death penalty } \\
\text { reinforced by the Decision of the Constitutional Court (MK) Number } \\
203 / \text { PUU-V / } 2007 \text { dated October } 30^{\text {th }} \text {, 2007, be carried out } \\
\text { carefully and pay attention to the rights of death row inmates who are } \\
\text { in the stage after the verdict will wait for the period of clemency, and } \\
\text { then will wait for the execution of the death sentence. The disparity } \\
\text { in narcotics penalty decisions is caused by several factors, namely the } \\
\text { difference in the philosophy of punishment, the factor of the absence } \\
\text { of criminal guidance, the factor of the independent judicial authority, } \\
\text { the factor of authority of the judge's decision. In this case there will } \\
\text { be discrimination between dealers who are given a decision by the } \\
\text { judge, in the case of a sentence that is not in accordance with its } \\
\text { portion., regarding it should be associated with evidence found. } \\
\text { Therefore, special rules are needed regarding the death penalty } \\
\text { associated with narcotics evidence, for example having } 5 \mathrm{~kg} \text { of } \\
\text { narcotics can be sentenced to death, without having gaps like what } \\
\text { happened in article } 114 \text { paragraph }(2)\end{array}$ \\
\hline
\end{tabular}

Corresponding Author: Yogi Prasetya Sinambela, Universitas Muhammadiyah Sumatera Utara, Indonesia Tel.+62812-6047-395. E-mail: prof.sumarsih@gmail.com

(C) Yogi Prasetya Sinambela

This is an open access article under the CC BY-SA 4.0 international license.

\section{Introduction}

Based on KBBI (Kamus Besat Bahasa Indonesia), disparity is difference and distance. In the same case, the law should not be justified for applying different rules. In legal science, it is commonly known as disparity (disparity of sentencing). It means that the same legal case must also apply the same rules. In addition, it is also to avoid discrimination that must be felt by the perpetrators, and to suing public injustice also provides 
legal certainty in the community (education). Harkristuti, Harkrisnowo stated that the disparity in the verdict is related to differences in criminal conviction for cases that are similar or equivalent in seriousness, without a clear reason or justification. An example of a disparity in a judge's decision occurred in narcotics crime cases. If the defendant is proven guilty, the statutory regulation has set a benchmark for the judge to give a prison sentence of between the shortest or the longest. For example, in Article 114 paragraph (2) of Law Number 35 Year 2009 concerning Narcotics:

Dalam hal perbuatan menawarkan untuk dijual, menjual, membeli, menjadi perantara dalam jual beli, menukar, atau menyerahkan Narkotika Golongan I sebagaimana dimaksud pada ayat (1) yang dalam bentuk tanaman beratnya melebihi 1 (satu) kilogram atau melebihi 5 (lima) batang pohon atau bentuk bukan tanaman beratnya 5 (lima) gram, pelaku dipidana dengan pidana mati, pidana penjara seumur hidup, atau pidana penjara paling singkat 6 (enam) tahun dan paling lama 20 (dua puluh) tahun dan pidana denda maksimum sebagaimana dimaksud pada ayat (1) ditambah 1/3 (sepertiga).

In the case of offering to be sold, to sell, to buy, become an intermediary in buying and selling, exchanging, or submitting Type I Narcotics as referred to in paragraph (1) in the form of plants weighing more than 1 (one) kilogram or exceeding 5 (five) tree trunks or non-plant form weighing 5 (five) grams, the offender is sentenced to death sentence, life imprisonment, or imprisonment for a minimum of 6 (six) years and a maximum of 20 (twenty) years and a maximum fine as referred to in section (1) plus 1/3 (one third).

Based on the provision of the sanctions, the judge has the freedom to impose sentences between capital punishment, life imprisonment, and imprisonment ranging from 6 years to 20 years and a maximum fine of Rp 10 billion plus $1 / 3$ (one third).

Capital punishment, as a final sanction option with the intention of providing a deterrent effect and as a means of maintaining normative order is still legal in Indonesia positive law (ius constitutum).

Justification for the death penalty in Indonesia positive law, legally-normatively can be referred to the provisions of article 10 of the Criminal Code (KUHP) which states that the death penalty as a type of primary crime in force in Indonesia. The existence of capital punishment in the legal system in Indonesia is listed in the Criminal Code and other regulations which are listed in Article 104 of the Criminal Code offense, planned murder listed in article 340 of the Criminal Code and in the Lex specialist regulation, namely the Narcotics distribution offense that provides for capital punishment, this is stated in Article 113 section (2) and 114 section (2) Law Number 35 of 2009 concerning Narcotics and capital punishment for the perpetrators of criminal acts of Terrorism (Law No. 15 of 2003) All of them according to the perspective of Indonesian criminal law are included in the category of extraordinary crimes.

The problems regarding criminal disparities that have grown in the enforcement of the death penalty certainly have an inevitable result. As a result of this striking criminal disparity, according to Edward M. Kennedy, it is relevant with Barda Nawawi ialah: who stated that:

1. Maintaining the growth or development of cynical feelings of the community towards the existing criminal system

2. Failure to prevent crime

3. Encouraging the occurrence of criminal acts

4. Obstructing corrective actions against violators.

Based on Edward M. Kennedy's perspective, it can be known that the consequences of criminal disparity are not in accordance with the objectives of criminal law and the spirit of criminal philosophy. Criminal disparity is increasingly causing chaos in society, not only hurting people's sense of justice, but also encouraging people to commit criminal acts. Furthermore, this condition is a form of failure of criminal law enforcement, where law enforcement is even interpreted as something trivial by the public.

A legal fact can be seen from various points of view, in this case, there are also legal experts who disagree that disparity only has a negative impact so it must be minimized, they do not view criminal disparity as a mistake or bodily defect in criminal law enforcement in Indonesia. In connection with this, Oemar seno Adji believed that disparities in punishment could be justified, such as in the following cases:

1. Penalty disparity can be justified against a rather severe sentence of offense, but the disparity in punishment must be accompanied by clear justification reasons

2. Criminal disparity can be justified if it is reasonable or reasonable.

Based on the background described above, the author is interested in examining the disparity in capital punishment in Indonesia with the following problem formulation. 
1. How is the Arrangement of Death Penalty Acts against Narcotics Traffickers?

2. How is the death penalty disparity against those who commit illegal narcotics trafficking?

3. How is the criminal law policy to overcome the death penalty disparity against narcotic traffickers?

\section{Literature Review}

In the study, the researcher used several theories relating to assessment as a basis for obtaining research results based on the problem to be studied. Therefore, the theory could be used for discussion in the study which includes:

\section{Absolute (Retributive) Theory}

Alegra, dkk gave the perspective about absolute theory. Absolute theory stated that:

"The state must punish the perpetrators because people have sinned (quia pacratum)".

In its original form, absolute theory rests on the thought of retaliation, which is the principle of retaliation. For example, eye for eye, tooth for tooth, etc. L.J. van Apeldoorn put forward his views on absolute theory. Absolute theory state that:

"The theory which justifies the existence of punishment is solely on the basis of offense committed. Only the sentence "quia pecattum est" is meant because people make a crime. The purpose of punishment lies in the punishment itself. Punishment is an absolute consequence of an offense, in return for a crime committed by the perpetrator".

Mula also expressed his perspective on the nature or essence of absolute theory. Absolute theory views that:

"Punishment is a retaliation for a mistake that has been committed so that it is oriented to the act and lies in the occurrence of the crime itself".

The theory puts forward that sanctions in criminal law are imposed solely because people who have committed a crime which is an absolute consequence must exist as retaliation to the person who committed the crime so that the sanction aims to satisfy the demands of the court.

\section{Relative Theory (Deterrence)}

Algra, et.al put forward their views on the definition and purpose of punishment, which is based on relative theory. Relative theory argues as follows:

"The state is punishing criminals as a means to an end. The purpose of the punishment is to frighten someone from carrying out evil deeds ".

L.J. van Apeldoorn put forward his views on the nature of relative theory. Relative theory atated that:

"Theories that seek justification of punishment outside the offense itself, namely in the objectives that must be achieved by threat of punishment and punishment. Punishment is given so that people do not make or commit crimes (ne peccetur) "

\section{Legal Certainty Theory}

Utrecht stated that legal certainty contains two meanings, namely first, the existence of general rules that make individuals know what actions may or may not be done, and secondly, in the form of legal security for individuals from the arbitrariness of the government because with the existence of general rules that individuals can know what the State may charge or do to individuals. Furthermore, the purposes of law which are approaching realistically are legal certainty and legal usefulness. The doctrine of legal certainty comes from the Juridical-Dogmatic teachings which is based on the positivistic school of thought in the world of law, which tends to see law as something autonomous, independent, because for adherents of this thought, law is nothing but a collection of rules. For adherents of this school, the purpose of law is nothing but guaranteeing the realization of legal certainty. Legal certainty is realized by the law by its nature which only makes a general rule of law. The general nature of the rule of law proves that the law does not aim to bring about justice or expediency, but merely for certainty.

\section{Research Methodology}

The research conducted normative legal research, with doctrinal normative juridical research approach. The nature of this research is analytical descriptive. Descriptive research is intended to provide as detailed data as possible about humans, circumstances or other symptoms. Furthermore, this study uses a statute approach (Statute Approach) and a case approach (Case Approach). The source of legal data in normative research was library data called legal material. The legal material is in the form of primary data obtained through interviews and secondary data obtained through library research. The data collection techniques in this study 
included primary, secondary and tertiary legal materials, as well as interviews. Furthermore, the level data analyzed in a qualitative analysis, the data collected was in the form of a logical and systematic description, then analyzed to obtain clarity of problem solving, then deductively drawn conclusions, namely from things that are general to something specific.

\section{Result and Discussion}

\section{Death Penalty Arrangement on Narcotics Traffickers}

\section{Number 5 of 1997 of the constitution concerning about Psychotropic}

In stopping and eradicating psychotropic abuse, Number 5 of 1997 of the constitution places the death penalty as one of the criminal sanctions. These provisions are contained in Article 59 section (2) which states:

"Bagi siapa saja yang menggunakan, memproduksi, mengedarkan, mengimpor, atau memiliki tanpa hak dengan dilakukan secara terorganisasi dipidana dengan pidana mati atau pidana penjara seumur hidup atau pidana penjara selama 20 (dua puluh) tahun dan denda sebesar Rp 750.000.000,00 (tujuh ratus lima puluh juta rupiah)"

"Anyone who uses, manufactures, distributes, imports, or has rights without being carried out in an organized manner is sentenced to death penalty or life imprisonment or imprisonment for 20 (twenty) years and a fine of Rp. 750,000,000.00 (seven hundred fifty million rupiah) "

\section{Number 22 of 1997 of the Constitutionconcerning about Narcotics}

Number 22 of 1997 of the constitution concerning about narcotics regulates several article formulations which can impose the death penalty, some of these articles are:

Article 80:

(1) Anyone without rights and violates the law

a. Producing, processing, extracting, converting, assembling, or providing Group I narcotics, sentenced to death or life imprisonment, or a maximum imprisonment of 20 (twenty) years and a maximum fine of Rp. 1,000,000,000.00 (one billion rupiah);

b. Producing, processing, converting, assembling, or providing Group II narcotics, sentenced to a maximum imprisonment of 15 (fifteen) years and a maximum fine of Rp 500,000,000.00 (five hundred million rupiah);

c. Producing, processing, converting, assembling, or providing Group III narcotics, sentenced to a maximum imprisonment of 7 (seven) years and a maximum fine of Rp 200,000,000.00 (two hundred million rupiah).

(2) If the criminal acts as referred to :

a. Section (1) subsection a is preceded by conspiracy and senteced with capital punishment or life imprisonment or imprisonment for a minimum of 4 (four) years and a maximum of 20 (twenty) years and a minimum fine of Rp. 200,000,000.00 ( two hundred million rupiah) and a maximum of Rp 2,000,000,000.00 (two billion rupiah);

b. Section (1) subsection b is preceded by conspiracy and senteced to a maximum imprisonment of 18 (eighteen) years, and a maximum fine of $\mathrm{Rp} \mathrm{1,000,000,000.00}$ (one billion rupiah);

c. Section (1) subsection c is preceded by consensus and senteced to a maximum imprisonment of 10 (ten) years, and a maximum fine of Rp. 400,000,000.00 (four hundred million rupiah)

(3) If the criminal acts as referred to :

a. Section (1) subsection a is carried out in an organized manner, sentenced to death sentence or life imprisonment or imprisonment for a minimum of 5 (five) years and a maximum of 20 (twenty) years and a minimum fine of $\mathrm{Rp} \mathrm{500,000,000.00}$ (five hundred million rupiah) and a maximum of Rp 5,000,000,000.00 (five billion rupiah)

b. Section (1) subsection b is carried out in an organized manner and senteced to a maximum imprisonment of 20 (twenty) years and a maximum fine of Rp. $3,000,000,000.00$ (three billion rupiah);

c. Section (1) subsection c is carried out in an organized manner and senteced to a maximum imprisonment of 15 (fifteen) years and a maximum fine of $\mathrm{Rp}$ 2,000,000,000.00 (two billion rupiah). 
Article 81:

(1) Anyone without rights and against the law:

a. bringing, sending, transporting, or transferring narcotics for Group I, shall be sentenced to a maximum imprisonment of 15 (fifteen) years and a maximum fine of Rp. 750,000,000.00 (seven hundred fifty million rupiah);

b. bringing, sending, transporting, or transferring narcotics for Group II, shall be punished with a maximum imprisonment of 10 (ten) years and a maximum fine of Rp. 500,000,000.00 (five hundred million rupiah);

c. bringing, sending, transporting, or transferring narcotics for Group III, shall be punished with a maximum imprisonment of 7 (seven) years and a maximum fine of Rp. 200,000,000.00 (two hundred million rupiah).

(2) If the criminal acts as referred to in section (1) are preceded by malicious agreement, then the criminal acts as referred to:

a. section (1) subsection a, shall be senteced to a maximum imprisonment of 2 (two) years and a maximum of 18 (eighteen) years and a minimum fine of Rp. $100,000,000.00$ (one hundred million rupiah) and a maximum of $\mathrm{Rp}$. 2,000,000,000.00 (two billion rupiah)

b. section (1) subsection $b$, shall be senteced to a maximum imprisonment of 12 (twelve) years and a maximum of Rp. 1,000,000,000.00 (one billion rupiah);

c. section (1) subsection c, shall be senteced to a maximum imprisonment of 9 (nine) years and a maximum of Rp. 500,000,000.00 (five hundred million rupiah).

(3) If the criminal acts as referred to

a. Section (1) Subsection a is carried out in an organized manner, shall be liable to a death convicting or life imprisonment, or a maximum convicting of 4 (four) years and a maximum of 20 (twenty) years and a minimum fine of Rp. $500,000,000.00$ (five hundred million rupiah) and a maximum of $\mathrm{Rp}$. $4,000,000,000.00$ (four billion rupiah)

b. section (1) subsection b is carried out in an organized manner, shall be punished with a maximum imprisonment of 15 (fifteen) years and a maximum fine of Rp. 2,000,000,000.00 (two billion rupiah);

c. section (1) subsection $\mathrm{c}$ is carried out in an organized manner, shall be punished with a maximum imprisonment of 10 (ten) years and a maximum fine of Rp. 1,000,000,000.00 (two billion rupiah).

Article 82:

(1) Anyone without rights and against the law:

a. importing, exporting, offering to sell, distributing, selling, buying, handing, receiving, brokering in buying and selling, means of exchanging narcotics Category I, senteced with capital punishment or life imprisonment, or life imprisonment, or most imprisonment 20 (twenty) years old and a maximum fine of Rp. 1,000,000,000.00 (one billion rupiah);

b. importing, exporting, offering to sell, channeling, selling, buying, handing, receiving, becoming an intermediary in buying and selling, or exchanging Group II narcotics, being sentenced to a maximum imprisonment of 15 (fifteen) years and a fine of Rp. 500,000,000.00 (five hundred million rupiah);

c. importing, exporting, offering to sell, channeling, selling, buying, handing, receiving, becoming an intermediary in buying and selling, or exchanging Group III narcotics, imprisoned for a maximum of 10 (ten) years and a fine of Rp. 300,000,000.00 (three hundred million rupiah).

(2) If the criminal acts as referred to in section (1) are preceded by malicious agreement, then the criminal acts as referred to:

a. section (1) subsection a, shall be senteced to capital punishment or life imprisonment or imprisonment for a minimum of 4 (four) years and a maximum of 20 (twenty) years and a minimum fine of Rp. 
200,000,000.00 (two hundred million rupiah) and a maximum of Rp. $2,000,000,000.00$ (two billion rupiah);

b. section (1) subsection $b$, shall be liable to a maximum imprisonment of 18 (eighteen) years and a maximum fine of Rp. 1,000,000,000.00 (one billion rupiah);

c. section (1) subsection c, shall be senteced to a maximum imprisonment of 12 (twelve) years and a maximum fine of Rp.750,000,000.00 (seven hundred fifty million rupiah);

(3) If the criminal acts as referred to :

a. Section (1) subsection a is carried out in an organized manner, senteced to death penalthy, or life imprisonment, or imprisonment for a minimum of 5 (five) years and a maximum of 20 (twenty) years and a minimum fine of Rp. 500,000,000.00 (five hundred million rupiah) and a maximum of Rp. 3,000,000,000.00 (three billion rupiah).

b. Section (1) Subsection b is carried out in an organized manner, senteced to a maximum imprisonment of 20 (twenty) years and a maximum of $\mathrm{Rp}$. $4,000,000,000.00$ (four billion rupiah);

c. Section (1) subsection c is carried out in an organized manner, senteced to a maximum imprisonment of 15 (fifteen) years and a maximum of $\mathrm{Rp}$. 2,000,000,000.00 (two billion rupiah).

(4) If the criminal acts as referred to:

a. Section (1) subsection a is conducted by a corporation, with a fine of no more than Rp. 7,000,000,000.00 (seven billion rupiah);

b. Section (1) subsection b is carried out by a corporation. a maximum fine of Rp. 4,000,000,000.00 (four billion rupiah);

c. Section (1) subsection c is carried out by a corporation, a maximum fine of Rp. 3,000,000,000.00 (three billion rupiah).

Article 96:

Whoever within a period of 5 (five) years commits a repeat of the criminal offense as referred to in Articles $78,79,80,81,82,83,84,85$ and Article 87 can be added to one third of the principal crime, except those senteced with a death penalthy, life imprisonment or imprisonment of 20 (twenty) years.

\section{Number 35 of 2009 of the constitution concerning about Narcotics}

Number 35 of 2009 of the constitution concerning about narcotics, there are capital punishment sanctions in Articles 113, 114, 118, 119, 121, 144, which are as follows:

Article 113 Section 2:

In the case of acts of producing, importing, exporting, or distributing Narcotics Group I as referred to in paragraph (1) in the form of plants weighing more than 1 (one) kilogram or exceeding 5 (five) tree trunks or in non-plant forms the weight exceeds 5 (five) gram, the perpetrator is senteced to death penalty, life imprisonment, or a crime of a minimum of 5 (five) years and a maximum of 20 (twenty) years and a maximum fine as referred to in paragraph (1) plus $1 / 3$ (one third).

Article 114 Section 2:

In the case of offering to sell, sell, buy, become an intermediary in buying and selling, exchanging, delivering, or receiving Narcotics of Group I as referred to in section (1) in the form of plants weighing more than 5 (five) tree trunks or in non-form plants weighing 5 (five) grams, the offender is sentenced to death sentence, life imprisonment, or imprisonment for a minimum of 6 (six) years and a maximum of 20 (twenty) years and a maximum fine as referred to in section (1) plus $1 / 3$ (one third).

Article 118 Section 2:

In the case of acts of producing, importing, exporting or distributing Narcotics Group II as referred to in section (1) weighing more than 5 (five) grams, the perpetrators shall be sentenced to death, life imprisonment, or imprisonment for a minimum of 5 (five) years and a maximum of 20 (twenty) years and a maximum criminal penalty as referred to in section (1) plus $1 / 3$ (one third).

Article 119 Section 2: 
In the case of offering to be sold, to sell and to buy, become an intermediary in buying and selling, exchanging, delivering, or receiving Narcotics of Group I as referred to in section (1) in the form of plants weighing more than 5 (five) tree trunks or in non-form plants weighing 5 (five) grams, the offender is sentenced to death sentence, life imprisonment, or imprisonment for a minimum of 5 (five) years and a maximum of 20 (twenty) years and a maximum fine as referred to in section (1) plus $1 / 3$ (one third).

Article 121 Section 2:

In the case of the use of Narcotics against other people or the provision of Narcotics of Group II for the use of other people as referred to in section (1) results in another person dying or permanently disabled, the perpetrators shall be senteced to death penalty, life imprisonment, or a prison sentence of at least 5 (five) years and a maximum of 20 (twenty) years and a maximum criminal penalty in section (1) plus $1 / 3$ (one third).

\section{Article 133 Section 1:}

Any person who orders, gives or promises something, gives an opportunity, encourages, makes it easy, coerces with threats, coerces forcefully, deceives, or entices children who are not old enough to commit a crime as referred to in Article 111, Article 112, Article 113, Article 114, Article 115, Article 116, Article 117, Article 118, Article 119, Article 120, Article 121, Article 122, Article 123, Article 124, Article 125, Article 126, and Article 129 are senteced to the death penalty or life imprisonment, or imprisonment for a minimum of 5 (five) years and a maximum of 20 (twenty) years and a fine of at least Rp 2,000,000,000.00 (two billion rupiah) and a maximum of Rp 20,000,000,000, 00 (twenty billion rupiah).

Law Amendment Number 22 of 1997 Regarding Narcotics is motivated by:

That Narcotics crime has been transnational in nature which is carried out using high modus operandi, sophisticated technology, supported by a wide network of organizations, and has caused many victims, especially among the young generation of the nation which is very dangerous to the lives of the people, nation, and country so that Number 22 of 1997 of the constitution concerning about narcotics is no longer in accordance with the development of the situation and conditions that are developing to tackle and to eradicate the crime.

\section{The Death Penalty Disparity Against Narcotic Trafficking}

Based on the results of research that had been done showed that the facts of the trial is known that the decision of 572 K/Pid.Sus/2013 with a decision of 699 / Pid.B / 2015 / PN Mdn. Charged with the same indictment, namely article 114 paragraph (2) and article 112 section (2).

Article 114 section (2) which were indicted to the two defendants contain as follows:

In the case of offering to be sold, to sell, and to buy, become an intermediary in buying and selling, exchanging, delivering, or receiving Narcotics of Group I as referred to in section (1) in the form of plants weighing more than 1 (one) kilogram or exceeding 5 (five) tree trunks or in the form of non-plants weighing 5 (five) grams, the offender is sentenced to capital punishment, life imprisonment, or a maximum imprisonment of 6 (six) years and a maximum of 20 (twenty) years and a maximum fine as referred to in section (1) plus 1 (3) one third.

Based on the description of the article, the two defendants are in accordance with the legal facts in the trial and the Prosecutor's indictment correctly and convincingly has fulfilled the elements of article 114 section (2).

Whereas based on this there has been a disparity in the decision in which the sentences were very much different although fulfilling the same elements, namely the conviction of the defendant Yap Wai Choong on the decision of $572 \mathrm{~K} /$ Pid.Sus / 2013 was senteced to death penalty while Ucok Roy Lubis on the 699 decision / Pid.B / 2015 / PN was sentenced to 11 (eleven) years imprisonment even far lighter than charged by the Public Prosecutor.

Based on the above the authors argued that there has been a Disparity in the decision between the decision $572 \mathrm{~K}$ / Pid.Sus / 2013 with 699 / Pid.B / 2015 / PN. In addition, there is a difference in the decision between the sentence to death penalty with imprisonment, which if left developing, there will be legal uncertainty that will harm the public who are caught as perpetrators of the crime of narcotics illicit trafficking, and will even lead to a sense of injustice against the perpetrators sentenced to death penalty while the other perpetrators are only sentenced to prison and the disparity of the decision is also contrary to the principle of equality before the law (Equality before the law).

There are several factors that cause criminal disparity, as follows.

\section{The Difference of Criminal Philosophy Factor}


Philosophical differences held by court judges can be a factor causing criminal disparities in narcotics crime cases. For example, if a panel of district court judges has a retributive philosophy of retribution that is backward looking while the Supreme Court panel of judges has a philosophy of utilitarian punishment, what happens in the product of the decision is criminal disparity. But if the panel of judges in the district court, high court, and Supreme Court both have a forward-looking orientation in bringing down the criminal (according to the understanding of utilitarianism), then criminal disparity can be minimized. To reinforce this argument, it is better to depart from Jon J. Lambiras's view which says differences in views can be in the form of conditions where judges with differing views might arrive at different conclusions (criminal rulings) regarding differing views given or indicated in facts in decisions.

\section{The Absence of Criminal Guidelines Factor}

The absence of sentencing guidelines for court judges in Indonesia is a factor causing criminal disparities in narcotics crime cases. Criminal guidelines in Indonesia are not specifically as a standard guideline for court judges in Indonesia which can be used as a guideline in convicting crimes such as those already owned by the United States

\section{ndependent Judicial Authority Factor}

The existence of independent judicial authority (judicial independence) given to the judges is also a factor causing the occurrence of criminal disparities in criminal cases in general and narcotics crime cases in particular. The authority of the court has been regulated in Law Number 48 of 2009 concerning Judicial Power as well as guiding judges in carrying out their duties and authority in adjudicating criminal cases.

\section{Judge Discretion Factor}

The granting of discretion to court judges in Indonesia can also be a factor that has the potential to cause criminal disparities in criminal cases in general and narcotics crime cases in particular. Hikmahanto Juwana said that discretion is a decision that comes from wisdom (wisdom) which is owned by an authorized official. The definition of discretion in the written law included in Law Number 48 of 2009 concerning Judicial Power has no legal provisions.

\section{The Application of the Death Penalty for Narcotics Traffickers}

Death penalty in Indonesia is regulated in Article 10 of the Indonesian Criminal Code (KUHP), which contains two types of sentences, namely the main sentence and additional punishment. The basic sentence consists of the death penalty, imprisonment, imprisonment and fines. Additional punishment consists from revocation of certain rights, confiscation of certain goods, and announcement of the judge's decision. In later developments, there are several laws that contain the threat of capital punishment, namely Law Number 22 of 1997 which was amended by Number 35 of 2009 concerning Narcotics, No. 5 of 1997 concerning Psychotropics, Number 26 of 2000 concerning Human Rights Courts, and Number 31 of 1999 Number 1 of 2002 concerning Corruption Crimes.

However, in overcoming the death penalty disparity against narcotic traffickers to create justice is by reforming the criminal law (penal reform) through criminal law policies, namely the inclusion of criminal acts of narcotics and psychotropic abuse into the Criminal Code (RUU KUHP) of 2012.

These provisions are contained in Chapter XVII of Narcotics and Psychotropic Abuse Acts Article 504Article 531. Specifically narcotics criminal acts are regulated in the second paragraph of Narcotics Abuse Acts Article 504-Article 522. Of the 19 articles governing narcotic offenses, there are 6 articles that specify the narcotics crime the death penalty for prohibited acts includes Article 506 paragraph (2), 507 paragraph (2), 509 paragraph (2), 511 paragraph (2), 512 paragraph (2), and Article 514 paragraph (2). Related to the formulation / legislative policy that will be carried out by the government how about capital punishment in the upcoming narcotics law, in this case the author will express some opinions of the scholars below. A. Muhammad Asrun argued, "a correct understanding of the imposition of the death penalty related to extraordinary crimes such as narcotics crimes must be seen as an effort to protect the" right to life "(many people).

Oemar Senoadji argues "as long as our country is still determined, wrestling with its own life which is threatened by danger, as long as the legal order of society is confused and endangered by elements who do not know humanity, it still needs death penalty". The death penalty is also in line with the objective of realizing a number of legal functions, including the function of education for other members of the community, that extraordinary crimes which greatly disturb the community as a whole, if proven to be carried out, the culprit will be punished by capital punishment. Achmad Ali further stated that capital punishment for the Indonesian state was still needed for those who committed serious crimes, planned 
killings that were carried out in a sadistic manner, including perpetrators of "genocide" and "crime againt humanity", drug dealers, "high-class" corruptors, and terrorists.

\section{Conclusion}

Based on the results of the above, it can be concluded that the regulation of the death penalty against drug dealers is regulated in Law Number 35 of 2009 concerning Narcotics in several articles, namely, Article 114 section 2, Article 119 section 2, Article 121 section 2 but in the implementation of the Punishment death does not contradict the constitution and Human Rights as stated in the contents of the Constitutional Court ruling Number 2-3 / PUUV / 2007 states that the death penalty does not conflict with the constitution because the right to live in the spirit of The 1945 Constitution of The Republic of Indonesia.and the history of the Indonesian constitution is not intended as a right absolute and underogable or rights that can be restricted.

Furthermore, there has been a disparity in the Decision between the decision $572 \mathrm{~K} / \mathrm{Pid}$. Sus / 2013 with 699 / Pid.B / 2015 / PN, which in this case there is a difference in the decision between the decision sentenced to death and imprisonment, which if allowed to develop there will be uncertainty law that will harm the public who are caught as perpetrators of narcotics illicit trafficking, will even cause a sense of injustice against the perpetrators sentenced to death while the other perpetrators are only sentenced to prison and the decision disparity is also contrary to the principle of equality before the law (Equality before the law). Then the role of government as policy maker is needed to overcome the problem of decision disparity in narcotics cases.

In overcoming the disparity of the death penalty against illicit traffickers of narcotics, it can be minimized by the guidelines of punishment and the principle of proportionality. Therefore, it is hoped that the government will immediately enact a new RUU-KUHP. Which in the case of capital punishment is the last alternative in accordance with the principle of ultimum remidium and also given time in 10 years to give time to the senteced person while examining a case whether it is appropriate to be sentenced to death. As well as continuing the program to eradicate criminal acts of narcotics illicit trafficking but do not discriminate against the sentences handed down so that there is no discrimination against people who are accused of being criminals of narcotics trafficking, it is expected to provide penalties in accordance with the portion committed by the senteced person in matters relating to evidence he has.

\section{References}

Abdur Rohim, “Hukuman Mati Problem Legalitas \& Kemanusiaan” Malang: Intrans Institute 2015

Achmad Ali, Menguak Tabir Hukum (Suatu Kajian Filosofis dan Sosiologis), Penerbit Toko Gunung Agung, Jakarta, 2002

Adami Chazawi. "Pelajaran Hukum Pidana Bagian I, Jakarta:Raja Grafindo 2002

Andi Hamzah., “Bunga Rampai Hukum Pidana dan Acara Pidana”. Jakarta: Ghalia Indonesia. 2001.

Andi Hamzah dan A. Sumangelipu, "Pidana Mati Di Indonesia Masa Lalu, Kini dan di Masa Depan, Jakara:Ghalia Indonesia. 1985.

Amiruddin dan Zainal Asikin, "Pengantar Metode Penelitian Hukum”, (Jakarta-Rajawali Pers, 2013)

Arief Barda Nawawi, Pembaharuan Hukum Pidana Dalam Perspektif Kajian Perbandingan, Citra Aditya Bakti, Bandung. 2011.

AR. Sujono dan Bony Daniel, Komentar \& Pembahasan Undang-Undang Nomor 35 Tahun 2009 tentang Narkotika, Cetakan Pertama, Sinar Grafika, Jakarta, 2011.

Atet Sumanto, "Efektifitas Pidana Mati Dalam Proses Penegakan Hukum Tindak Pidana Narkotika” Jurnal Perspektif Volume 22 No. 1 Tahun 2017 Edition Januari

Bagir Manan, Kekuasaan Kehakiman Republik Indonesia, (Bandung: LPPM-UNISBA, 1995)

Barda Nawawi Arief, Bunga Rampai Kebijakan Hukum Pidana (Perkembangan Penyusunan Konsep KUHP Baru) (Buku III), Cetakan Ketiga, Fajar Interpratama Offset, Jakarta, 2011

Barda Nawawi Arief, Bunga Rampai Kebijakan Hukum Pidana (Perkembangan Penyusunan Konsep KUHP Baru), Cet. 3, Kencana Prenada Group, Jakarta, 2011.

Barda Nawawi Arief, Teori-teori dan kebijakan Pidana, Bandung: Alumni, 1984

Bambang Sugeng Rukmono, "Hakikat Pelaksanaan Hukuman Mati Ditinjau Dari Perspektif Hak Asasi Manusia”. Jakarta: PT Raja Grafindo Persada. 2016

Cst Kansil, Christine , S.T Kansil, Engelien R, Palandeng dan Godlieb N Mamahit, Kamus Istilah Hukum, Jakarta, 2009

Devy Iryanthy Hasibuan,Disparitas Pemidanaan Terhadap Pelaku Tindak Pidana Narkotika, USU Law Journal, Vol.3.No.1 (April 2015) 
Dharana Lastarya. "Narkoba, Perlukah mengenalnya” Jakarta:Pakarkarya. 2006

Dominikus Rato, Filsafat Hukum Mencari: Memahami dan Memahami Hukum, Laksbang Pressindo, Yogyakarta, 2010,

Dwika, "Keadilan dari Dimensi Sistem Hukum", http://hukum.kompasiana.com. (02/04/2011), Accessed on $16^{\text {th }}$ March 2018 At $09.04 \mathrm{Wib}$.

Erwin Mappaseng. "Pemberantasan dan Pencegahan Narkoba yang dilakukan oleh Polri dalam Aspek Hukum dan Pelaksanaannya". Surabaya:Buana Ilmu.

Ediwarman, "Monograf Metodologi Penelitian Hukum Panduan Penulisan Skipsi, Tesis. Dan Disertasi, Yogyakarta:Genta Publishing, Tahun 2016

Gilang Fajar Shadiq. Penegakan Hukum Terhadap Tindak Pidana Narkotika New Psychoactive Subtances Berdasarkan Undangundang Nomor 35 Tahun 2009 Tentang Narkotika.Jurnal Wawasan Yuridika Vol. 1|No.1|March 2017

Hikmahanto Juwana dalam Marwan Effendy, Diskresi, Penemuan Hukum, Korporasi \& Tax Amnesty Dalam Penegakan Hukum, (Jakarta: Referensi, 2012)

Hukum Online "Disparitas putusan hakim dalam perkara narkotika" from http://www.hukumonline.com/klinik/detail/lt5705da9c9e32d/disparitas-putusan-hakim-dalam-perkaranarkotika on 16th March 2019 at 00.23 a.m

Istilah hukum "disparitas" from https://istilahhukum.wordpress.com/2013/01/28/disparitas/ Accessed on $16^{\text {th }}$ March 2019 at 00.18 a.m

I Wayan Wardana, Kebijakan Formulasi Pidana Mati Dalam Tindak Pidana Narkotika Di Indonesia, Jurnal IUS|VolII|Nomor5 Agustus 2014

Julianan Lisa FR dan Nengah Sutrisna W. 2013. Narkoba, psikotropika dan gangguan jiwa tinjauan kesehatan dan hukum. Yogyakarta: Yuhamedika

Joop W. Koopmans and Arend H, Huussen Jr., Historical Dictionary of the Nederlands, (Lanham:Scarecrow Press. 2007

Kbbi, "Disparitas" from https://kbbi.web.id/disparitas Accessed on 12 March 2019 At 00.16 a..m.

Kurnia, "Ide Dasar dan Kebijakan Formulasi Pidana Mati Bersyarat Dalam Perspektif Pembaharuan Hukum Pidana di Indonesia" (Tesis Magister Ilmu Hukum, Program Pasca Sarjana Ilmu Hukum, Universitas Diponegoro, Semarang, 2004)

Muladi, “Lembaga Pidana Bersyarat Cet. 2,_Semarang:Alumni. 1992

M. Budiarto, "Pidana Mati dalam Perspektif Pembentukan Hukum Pidana Nasional," dalam: Jurnal Legislasi 2 (April, 2002)

M. Mufti Mubarok, Mati Syahid Mati Sangit: Di Balik Kematian Para Tertuduh, Surabaya: Java Pustaka Media Utama. 2008

Nelvitia Dan Sri "Pelaksanaan Hukuman Mati Perspektif Hak Asasi Manusia Dan Hukum Pidana di Indonesia" Yogyakarta:Graha Ilmul 2015

Nugraha Azel Putra, "Disparitas Putusan Hakim Dalam Perkara Nomor 122/Pid.B/2005/PN,PYK Dengan Putusan Nomor 57/PID/2006/PT.PDG" Jurnal JOM Fakultas Hukum Volume III Nomor 1 Februari 2016.

Nurul Widiasih (Disparitas pidana dalam kasus tindak pidana kekerasan fisik dalam rumah tangga di wilayah hukum Bandar lampung). Tesis Jakarta, juli 2009

Oemar Seno Adji, "Hukum-hukum pidana", (Jakarta-Erlangga, 1984)

Peter Mahmud Marzuki, Pengantar Ilmu Hukum, Kencana, Jakarta, 2008

Putusan Mahkamah Konstitusi Republik Indonesia Nomor 2-3/PUU-V/2007

Ronny Andri Prajitno, “Metode Penelitian Hukum dan Jurimetri, Jakarta:Ghalia Indonesia. 2010.

Robert Cribb, Historical Atlas of Indonesia, Honolulu: University of Hawaii. 2000

Riduan Syahrani, Rangkuman Intisari Ilmu Hukum, Penerbit Citra Aditya Bakti,Bandung, 1999

Salim Hs dan Erlies Septiana Nurbani, 2014. Buku Kedua Penerapan Teori Hukum Pada Penelitian Dan

Disertasi Dan Tesis. Rajawali Press. Jakarta

Soerjono Soekanto, “Pengantar Penelitian Hukum”, (Jakarta-UI-Press). Tahun 2014

ASHREJ Vol. 2, No. 1, 2020: 9- 19 
Sudarto, Kapita Selekta Hukum Pidana (Buku II), Alumni, Bandung, 1981

Tatas Nur Arifin, “Implementasi Rehabilitasi Pecandu Narkotika Dalam Undang-Undang Nomor 35 Tahun 2009 tentang Narkotika Sebagai Upaya Non Penal Badan Narkotika Nasional”, Jurnal Ilmiah, Fakultas Hukum Universitas Brawijaya Malang, 2013

Tongat, Pidana Seumur Hidup Dalam Sistem Hukum Pidana di Indonesia, Cetakan Pertama, Universitas Muhammadiyah Malang, 2004

Tri Fajar Nugroho, "Penjatuhan Pidana Mati Terhadap Pelaku Pengedar Narkotika”, Skripsi Universitas Lampung, Tahun 2016

Umar Anwar, Penjatuhan Hukuman Mati Bagi Bandar Narkoba Ditinjau Dari Aspek Hak Asasi Manusia.Jurnal Legislasi Indonesia Vol. 13 N0. 03-September 201

US Govt., "To Abolish The Death Penalty: Hearings" dalam: Ninetieth Congress, $2^{\text {nd }}$ session, on S. 1760. March 20,21, and July 2, 1968, New York: U.S Govt. Print. Off. 1970,

Waluyadi.Kejahatan, Pengadilan dan Hukum Pidana, Mandar Maju, Bandung. 2009

Zainuddin Ali, “Metode Penelitian Hukum” Jakarta:Sinar Grafika. 2015 